\title{
Effect of High Density on Spacing Behavior, Social Behavior and Weight Gain of Calves
}

\author{
Seiji Kondo, Hiroyuki Asano*, Susumu Nishino* \\ and Yasushi Asahida \\ Faculty of Agriculture, Hokkaido University, \\ Kita-ku, Sapporo-shi 060 \\ * Department of Dairy Science, Rakuno University \\ Ebetsu-shi 069
}

(Received July 18, 1991)

\begin{abstract}
Spatial and social behavior and weight gain under different density situations were compared in two groups of 6 castrated calves at 5 months of age. The one group was kept in a $14.4 \times 28.8 \mathrm{~m}$ lot (group LD, $69.1 \mathrm{~m}^{2} /$ calf), and the other was in a $3.0 \times 9.0 \mathrm{~m}$ indoor sloped floor pen (group HD, $4.7 \mathrm{~m}^{2} / \mathrm{calf}$ ). Each group was kept in that situation during 7 weeks, and behavior observations were made at the 3rd and 6 th weeks for 7 consecutive days. During observations, lying behavior, distances between calves and agonistic behavior were recorded.

Diurnal lying pattern did not differ from each group. Mean distance to nearest neighbor ( $\mathrm{rA}$ ) in group LD was significantly larger than that for group HD $(\mathrm{P}<0.01)$, while the ratio of $\mathrm{rA}$ to expected $\mathrm{rA}$ assuming random distribution at each density indicated that group LD had a tendency of aggregation $(0.4-0.5)$, while calves in group HD showed random distribution (0.9-1.0). Agonistic encounters were observed less in group LD during the 3 rd week than in group HD (295 vs. 580 ), though during the 6 th week the rate of encounters was similar in each group (about 600 for each). Fighting in group LD comprised a greater proportion of the total enconters than in group HD, while bunting-pushing and threatening-avoiding comprised larger proportion in group HD than in group LD. Dominance rank orders were significantly correlated $(\mathrm{P}<0.01)$ between the 3rd and 6th weeks for group HD, but not for group LD. Mean body weight gains did not differ between two groups for the first 4 weeks $(0.89$ and $1.00 \mathrm{~kg} /$ day for groups LD and HD), but calves kept at high density had significantly $(\mathrm{P}<0.05)$ lower body weight gains during from the 5 th to 7 th weeks, 1.22 and $0.89 \mathrm{~kg} / \mathrm{day}$ for groups LD and $\mathrm{HD}$, respectively.
\end{abstract}

Anim. Sci. Technol. (Jpn.) 63 (2) : 141-147, 1992

Key words : calf, high density, spacing behavior, agonistic behavior, weight gain

Keeping animals in a small area has some economic advantages, but spatial restriction affects an animal's behavior. Under crowded conditions, animals always have to invade other's social force fields ${ }^{13)}$. This could induce some social interactions. High density influences egg and meat productions in poultry ${ }^{14)}$, and the behavior of swine is also influenced by high density ${ }^{3)}$.

In cattle, the relationship between density and behavior is different from other animals. Fox ${ }^{5)}$ suggested that high density in cattle groups may not result in increased aggression as in swine and poultry, but may have less obvious effects. Kondo et al. ${ }^{9)}$ reported that calves changed their spatial and social behav- 
ior, as space was reducced from $70 \mathrm{~m}^{2} /$ calf to $8 \mathrm{~m}^{2} / \mathrm{calf}$, and observed that individual variation of weight gain was greater for calves at highest density than that at low density.

The present study sought to determine the difference of behavior and performance between calf-groups kept at low and high density, that is, $69.1 \mathrm{~m}^{2} /$ calf and $4.5 \mathrm{~m}^{2} /$ calf.

\section{Materials and Methods}

Twelve male Holstein calves were reared individually in separate pens from one week of age. At 5 months, they were castrated, and randomly allotted to form two groups of 6 , of which mean and standard deviation of body weight was 155.6 and $6.5 \mathrm{~kg}$. The one group kept in a $14.4 \times 28.8 \mathrm{~m}$ outdoor lot (group LD), while the other was kept in a $3.0 \times 9.0 \mathrm{~m}$ pen in a barn (group HD). The density of them was 0.014 calf $/ \mathrm{m}^{2}\left(69.1 \mathrm{~m}^{2} /\right.$ calf $)$ and $0.222 \mathrm{calf} / \mathrm{m}^{2}$ $\left(4.5 \mathrm{~m}^{2} /\right.$ calf $)$, respectively.

Schematic arrangement of the two pens is shown in Fig. 1. The lot for group LD was fenced by iron-net $1.2 \mathrm{~m}$ high and had a shelter $(2.7 \times 14.4 \mathrm{~m})$. The ground surface was covered with sand and relatively flat. The pen for group HD had a $10 \%$ sloped floor covered with concrete. Both the lot and the pen had the same size and type of feed trough $(2.7 \mathrm{~m}$ length), hay rack and waterer but different spatial arrangement. The experiment was conducted over the first 7 weeks after grouping.

Behavioral observations were made during the $3 \mathrm{rd}$ week and the 6 th week. The activities and position of each calf were recorded at $15 \mathrm{~min}$ intervals for 168 consecutive hours (7 days). The position of each calf was determined relative to a grid pattern $(1.8 \times 1.8 \mathrm{~m})$ drawn with slack lime on the ground of the lot (group LD), or determined in relation to a series of pillars which stood at $1.5 \mathrm{~m}$ intervals (group HD). The position of each calf was expressed as a series of $\mathrm{X}$ and $\mathrm{Y}$ coordinates and recorded on a microcomputer which calculated the mean distance to the nearest neighbor ( $\mathrm{rA}$ ) and the ratio $(\mathrm{R})$ of $\mathrm{rA}$ to the expected $\mathrm{rA}(\mathrm{rE})$ assuming random distribution in each density situation ${ }^{1)}$.

Agonistic behavior in each group was observed for 1 hour before and after every feeding ( $7: 00-9: 00$ and $15: 00-17: 00)$, and was recorded according to three categories : buntingpushing, threatening-avoiding and fighting. The dominance rank order in each group was

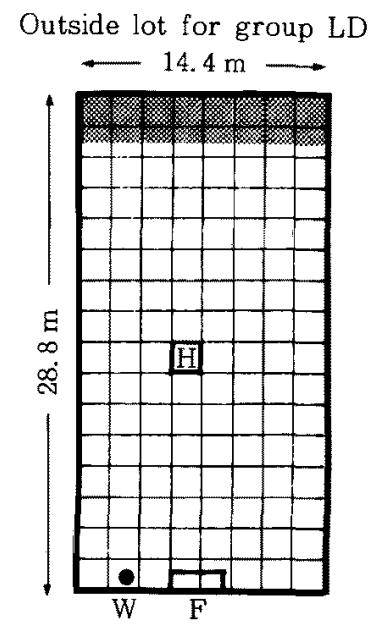

Sloped barn for group HD

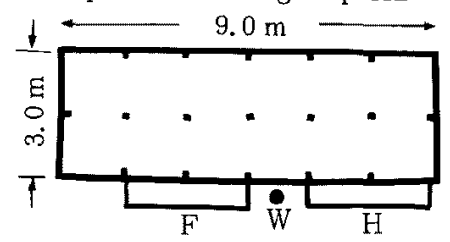

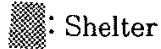
H : Hay rack
F : Feed trough
W: Waterer

Fig. 1. The experimental sites. 
determined on the basis of the results of the agonistic behavior. For the observation in darkness, the lot and pen each were lighted by six $300 \mathrm{w}$ searchlights.

Calves in both groups received concentrate twice a day $(8: 00$ and $16: 00)$. From the lst to the 5 th week, they were fed $2.0 \mathrm{~kg}$ concentrate $/$ day $/ \mathrm{calf}$, and fed $3.0 \mathrm{~kg}$ and $4.0 \mathrm{~kg} / \mathrm{day} /$ calf for the 6 th and 7 th weeks, respectively. Hay and water were available ad libitum. The amount of hay residue was measured weekly to estimate hay consumption per group. The body weight of each animal was measured at weekly intervals.

\section{Results and Discussion}

For both groups, lying mainly occurred in the nighttime and before and after noon, and there was no essential difference between groups LD and HD. Konno et al. ${ }^{9)}$ showed lying pattern was not changed when lot space was reduced from 70 to $8 \mathrm{~m}^{2}$ /animal in 12 calves. In this study, the behavioral patterns was not changed when space allowance for calves was reduced to $4.5 \mathrm{~m}^{2} /$ animal.

The mean distances to nearest neighbor ( $\mathrm{rA}$ ) are shown in Table 1. Calves in group HD had shorter distances to neighboring calves than those in group LD in the 3rd and 6th weeks $(\mathrm{P}<0.01)$. The $\mathrm{rA}$ of both groups were larger in the 6th week than in the $3 \mathrm{rd}$ week, though differences were not significant between periods. A physical restriction of space decreased actual distances between calves.

Table 1. Mean distances to nearest neighbor ( $\mathrm{rA}, \mathrm{m})$

\begin{tabular}{|c|c|c|}
\hline & \multicolumn{2}{|c|}{ Group } \\
\hline & $L D$ & HD \\
\hline \multicolumn{3}{|l|}{ Week } \\
\hline & $1.7^{\mathrm{a}}$ & $1.0^{b}$ \\
\hline & $2.3^{\mathrm{a}}$ & $1.2^{b}$ \\
\hline Mean & 2.0 & 1.0 \\
\hline
\end{tabular}

$a-b: P<0.01$
The rA was about $2.0 \mathrm{~m}$ in group $\mathrm{LD}$ and about $1.0 \mathrm{~m}$ in group HD. These distances are in the range of $\mathrm{rA}$ which was reported in spatial experiment in groups of 2 to 6 calves in various space allowance ${ }^{8)}$, and slightly smaller than those of cows ${ }^{6)}$.

Fig. 2 shows the ratio (R) of $\mathrm{rA}$ to $\mathrm{rE}$, which was a parameter to compare the degree of dispersion or aggregation in a group ${ }^{12)}$. In group $\mathrm{LD}, \mathrm{R}$ was about 0.4 and 0.5 in the $3 \mathrm{rd}$ and 6 th weeks, respectively, which indicates a significant aggregation on individuals in a group. The group HD, $\mathrm{R}$ was about 0.9 and 1.0 in the $3 \mathrm{rd}$ and 6 th wecks respectively, and did not differ from random expectation. MCBRIDE ${ }^{11)}$ described that an animal society required that animals to be distributed nonrandomly in physical space as a result of their spacing behavior relative to conspecifics. Calves at the density of $4.5 \mathrm{~m}^{2} /$ calf in this

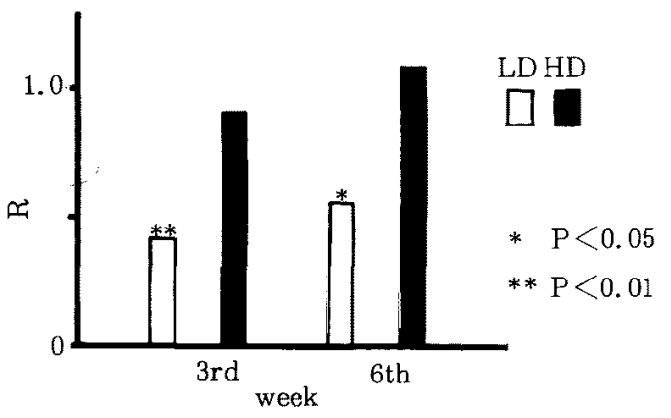

Fig. 2. Ratio (R) of observed distance to nearest neighbor ( $\mathrm{rA}$ ) to the expected distance to nearest neighbor assuming random distribution ( $\mathrm{rE}$ ) in each density situation.

Table 2. Frequency of agonistic behavior summed over observation from $7: 00-9: 00$ and $15: 00-17: 00$

\begin{tabular}{llll}
\hline \hline & \multicolumn{2}{c}{ Group } \\
\cline { 3 - 4 } & & LD & HD \\
\hline Week & & & \\
& 3rd & 295 & 580 \\
& 6th & 688 & 611 \\
\hline
\end{tabular}


study could not maintain their non-random spacing behavior, thus they would adapt behaviorally to this high density condition by changing their spacing to be a random. KILEY-WORTHINGTON ${ }^{7}$ considered that crowding strongly influences the social behavior in an animal group, and listed typical changes of behavior under crowded conditions. The main change was an increase of aggression or attacks, and a change in dominance hierarchy toward either the establishment of a more rigid dominance order or total social disorganization.

The frequency of agonistic behavior in groups $L D$ and $H D$ was shown in Table 2. Group HD had more agonistic interactions than group LD in the 3rd week but not in the 6 th week. The result of period 1 shows more aggressive condition of animals in high density that in low density, though frequencies of agonistic behavior in the 6 th week shows no difference of agonistic behavior between densities. KILEY-WORTHINGTON ${ }^{7)}$ pointed out that frequency of aggression was changed by not only density but also a lot of other environmental factors. Frequency of agonistic
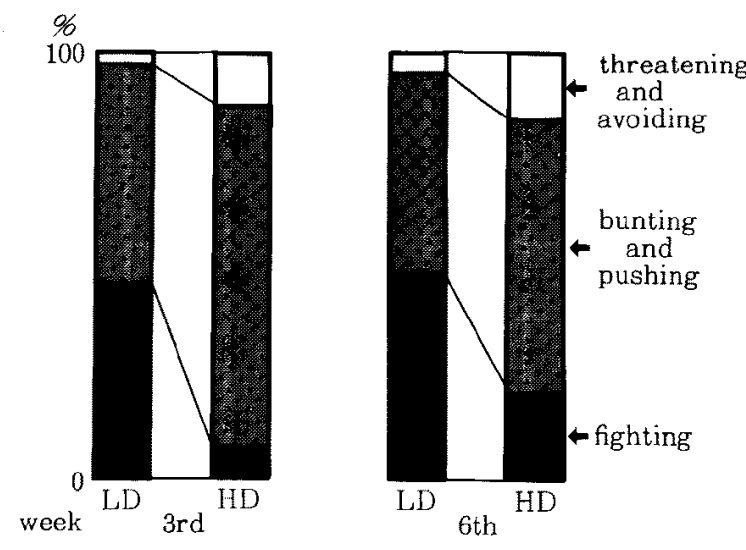

Fig. 3. Proportion(\%) of three agonistic behavior to total frequency of encounters. The agonistic behavior was observed between $7: 00^{-9}: 00$, and $15: 00-17: 00$ through consecutive 7 days in each period. behavior would not so good parameter to estimate social condition.

From results of encounters without fighting, the win-loss ratio was calculated to estimate dominance rank in the $3 \mathrm{rd}$ and 6 th weeks. In group LD, the Spearman rank correlation coefficient of estimated dominance ranks between the $3 \mathrm{rd}$ and 6 th weeks were not significant $\left(r_{S}=0.72\right)$, while in group $\mathrm{HD}$, the correlation of dominance rank between periods 1 and 2 was significant $\left(\mathrm{r}_{\mathrm{S}}=0.94, \mathrm{P}<0.05\right)$. These results suggested that social hierarchy was more strict in calves under high density than low density.

Fig. 3 shows the relative frequency of occurrence of three agonistic behavior types observed. The difference between the 3rd and 6 th weeks was little in both groups. In the group LD, threatening-avoiding behavior was the least frequent, while bunting-pushing and fighting behavior each occupied $40-50 \%$ of the total. In group HD, the most frequent agonistic behavior type was bunting-pushing. The proportion of threatening-avoiding observed in group $\mathrm{HD}$ was larger than that in group $\mathrm{LD}$, while the fighting in group $\mathrm{HD}$ was less frequent than $L D$.

Fighting in calf-group was sometime classified as a play behavior ${ }^{15}$. When the relationship between dominance and subordinate in animals was strictly established, the behavior of fighting would be less observed. The difference of proportion of each agonistic behavior between groups LD and HD suggested that high density accelerated to establish a strict relationships between dominance and subordinate of calves. This result also suggested the proportion of each agonistic behavior could be more useful parameter to evaluate the social conditions in a group rather than frequencies of agonistic interactions as described by Kondo and HurniK ${ }^{10)}$.

The mean hay consumption per group per week were $172.1 \mathrm{~kg}$ and $161.0 \mathrm{~kg}$ in groups LD and $H D$, respectively. This difference was not 


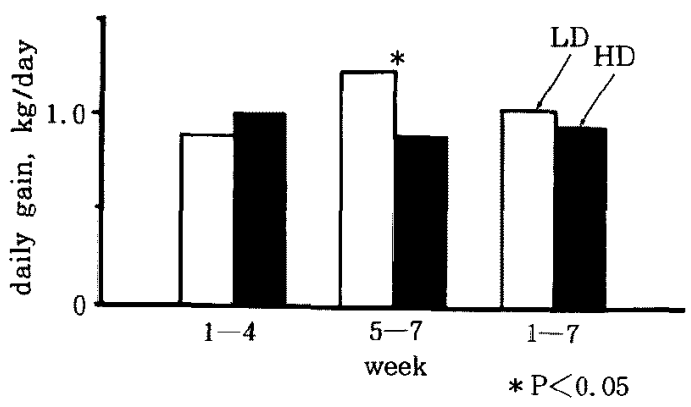

Fig. 4. Mean body weight gain in groups LD and HD during the first 4 weeks, the latter 3 weeks and throughout the 7 weeks.

statistically significant. The concentrate was entirely consumed during every feeding time in both groups.

Fig. 4 shows mean daily weight gain of each group from the lst to the 4 th week, from the 5th to the last week and throughout the experimental period. There was no significant difference in weight gain between the two groups from weeks 1 to $4(0.89$ and $1.00 \mathrm{~kg} /$ day for groups LD and HD) and overall (1.03 and $0.95 \mathrm{~kg} /$ day for groups LD and HD), but the calves in group HD gained significantly less weight $(P<0.05)$ than those in group LD from weeks 5 to 7 , that is, 1.22 and $0.89 \mathrm{~kg} /$ day for groups LD and $H D$, respectively. Table 3 shows coefficients of rank correlation $\left(\mathrm{r}_{\mathrm{s}}\right)$ between dominance rank order and weight gain in the 3rd and 6th weeks for both groups. None of the correlation coefficients was statistically significant.

Fox ${ }^{5)}$ showed overcrowding feedlot corrals would decrease efficiency and showed lower weight gains of cattle when allotted $1.9 \mathrm{~m}^{2}$ of space/animal than those allotted $3.7 \mathrm{~m}^{2}$ of space/animal. Fox ${ }^{5)}$ discussed that greatest reduction in daily gain occurred at the worst lot condition, and he implied it depended on the worst floor condition, which could be usually made by high density ${ }^{2}$. Thus, if the facilities employed a slatted floor, beef steers and heifers over $500 \mathrm{~kg}$ were best housed in groups
Table 3. Spearman rank correlation coefficients $\left(r_{s}\right)$ between weight gain and dominance rank order

\begin{tabular}{|c|c|c|}
\hline & \multicolumn{2}{|c|}{ Group } \\
\hline & $\mathrm{LD}$ & $\mathrm{HD}$ \\
\hline \multicolumn{3}{|l|}{ Week } \\
\hline $3 \mathrm{rd}$ & -0.66 & -0.20 \\
\hline 6th & -0.43 & +0.54 \\
\hline $\begin{array}{l}\text { Throughout } \\
\text { experiment }\end{array}$ & -0.20 & -0.21 \\
\hline
\end{tabular}

at a stocking density of 1.8 to $2.3 \mathrm{~m}^{2}$ of floor space $^{16)}$.

In this study, group HD was kept in sloped floor pens, which could make floor to be dry condition. In spite of employing such a floor system, weight gains of group HD was lower than that in group LD from the 5th to 7 th weeks. As feed intake of both groups was similar, the high density condition in group HD would influence on the feed conversion rate directly, as suggested by FISHER et al. ${ }^{4)}$ who compared performaces of calves kept in wide with narrow individual pens. Consequently, calves in high density could grow as well as those in low density up to 4 weeks, though they could not maintain such a growth rate after 5 weeks.

\section{Acknowledgment}

The authors would like to acknowledge the reviewing of this manuscript for Dr. J.F. Hurnik and Dr. A.B. Webster in the Department of Animal and Poultry Science, University of Guelph.

\section{References}

1) Clark, P.J. and F.C. Evans, Distance to nearest neighbor as a measure of spatial relationships in populations. Ecology, 35 : 445-453. 1954 .

2) Elam, J.C., Problem related to intensive indoor and outdoor beef production system. J. Anim. Sci., 32: 554-559. 1971.

3) Ewbank, R. and M.J. Bryant, Aggressive behavior amongst groups of domesticated 


\section{Kondo, Asano, Nishino and Asahida}

pigs kept at various stocking rates. Anim. Behav., 20 : 21-28. 1972.

4) Fisher, J.L., G.B. Peterson, S.E. Jones and J.A. Shelford, Two housing systems for calves. J. Dairy Sci., 68 : 368-373. 1985.

5) Fox, M.W., Farm animals-Husbandry, behavior, and veterinary practice. 81-119. University Park Press. Baltimore. 1984.

6) Fraser, A.F. and D.M. Broom, Farm animal behaviour and welfare. $3 \mathrm{rd}$ ed. 127 134. Bailliere Tindall. London. 1990.

7) Krley-Worthington, M., Behavioural problems of farm animals. 15-17. Oriel Press. Stockfield. 1977.

8) Kondo, S. and S. Nishino, Changes in spatial and social behavior of calves after grouping. Proc. 5th WCAP., 2: 815-816. 1983.

9) Kondo, S., H. Maruguchi and S. Nishino, Spatial and social behavior of calves in reduced dry-lot space. Jpn. J. Zootech. Sci., 55 : 71-77. 1984.

10) Kondo, S. and J.F. Hurnik, Stabilization of social hierarchy in dairy cows. Appl. Anim. Behav. Sci., 27 : 277-287. 1990.

11) McBride, G., Society evolution. Proc. Ecol. Soc. Aust., 1: 1-15. 1966.

12) McBrIDE, G., Behavioural measurement of social stess. in Adaptation of Domestic Animals. (HAFEz, E.S.E., ed.) 361-366. Lea and Febiger. Philadelphia. 1968.

13) McBride, G., Theories of animal spacing: the role of flight, fight and social dominance. in Behaviour and Environment. The Use of Space by Animals and Man. (Esser, A.H., ed.) 53-68. Plenum Press, New York-London. 1971.

14) Ringer, R.K., Adaptation of poultry to confinement rearing system. J. Anim. Sci., 32: 590-598. 1971.

15) Sambraus, H.H., Nutztierethologie. 49-127. Verlag Paul Parey. Berin. 1978.

16) WiLson, H.C., Beef cattle and veal calves. in The Care and Management of Farm Animals. (Sсотт, W.N., ed.) 29-52. Bailliere Tindall. London. 1978. 


\title{
高密度群飼が子牛の空間行動, 社会行動および 増体重に及汸す影響
}

\author{
近藤誠司・浅野洋之*・西埜 進*・朝日田康司 \\ 北海道大学農学部, 札幌市北区 060 \\ *酪農学園大学, 江別市 069
}

\begin{abstract}
高密度群飼が子牛の空間行動，社会行動および增体重に及ぼす影響を知る目的で，子牛を $4.5 \mathrm{~m}^{2} /$ 頭 および $69.1 \mathrm{~m}^{2} /$ 頭で 7 週間群飼とし，その群行動を比較検討した。

12 頭のホルスタイン種去勢子牛（5 か月齡，平均体重 $155.1 \mathrm{~kg}$ ）を2群に分け，それぞれ $69.1 \mathrm{~m}^{2}$ / 頭の屋外運動場（LD 群）上 $4.5 \mathrm{~m}^{2}$ /頭の群飼ペン（HD 群）で放し飼いとし，7週間飼養した，行動 観察は第 3 週および第 6 週に 7 日間連続して行ない，各個体の横卧行動および個体間の距離を記録した。 また朝夕の給飼の前後 1 時間に群内の敵対行動を押し合い，頭突き，押しのけ，威䓇，回避に分けて記 録した，各群は乾草および水を自由掑取とし，そのほ加に配合埕料を 5 週までは 1 日 1 頭当り $2 \mathrm{~kg}$ を 与元，6週目には $3 \mathrm{~kg}, 7$ 週目には $4 \mathrm{~kg}$ を給与した。体重測定は 1 週間隔で行なった.

横臥行動の日内バターンには群間に違いはなかった。平均最近接個体間距離（rA）は LD 群が約 $2 \mathrm{~m}, \mathrm{HD}$ 群が約 $1 \mathrm{~m}$ と有意な差 $(\mathrm{P}<0.01)$ があったが, rA とその期待值との比は LD 群が $0.4 \sim$ 0.5 と有意な集合性の分布 $(\mathrm{P}<0.05)$ を示したのに対して，HD群は $0.9 \sim 1.0$ 上ランダムな空間分 布であることを示した．敵対行動の頻度は 3 週目において LD 群 295 回, HD 群 580 回と高密度群飼 で約 2 倍の值となったが，6 週目では耐群とも600回程度でほぼ等しい值となった，两観察期間を通じ て，LD群では押し合いが多く，HD 群では頭突き，押しのけ，威跡，回避など一方的な敵対行動が 多かった。 また，3および 6 週の観察結果から算出したそれぞれの優劣順位は，LD 群では両順位間の 㥵関は低かったが，HD 群では有意な正の相関 $(\mathbf{P}<0.01)$ が得られ，高密度群飼では個体間の優劣関 倸がより蕨格であることが示埈された. 平均增体量 $(\mathrm{kg} / \mathrm{B})$ は 4 週目までは両群に差はなかったが， 後半の 5 から 7 週目では LD 群が 1.22 であったのに対して, HD 群は 0.89 之有意に低い值となり， 高密度で長期間群飼すると增体重に悪影響がでる可能性があることが示唆された。
\end{abstract}

日畜会報, 63 (2)：141-147, 1992 